\title{
TRUNCATED MULTILINGUAL REPERTOIRE IN INDIAN MIGRANT FAMILIES IN THREE CITIES OF EUROPE
}

\author{
Shahzaman Haque \\ Université de Grenoble III, \\ University of Tampere, and University of Gothenburg
}

\begin{abstract}
This paper outlines a case study of language choices between three Indian immigrant families residing in three different countries of Europe - France, Norway, and Finland. The issue is to focus on the language practices of the immigrant members when the verbal repertoire is composed of several languages owing to truncated competencies. What are the languages at their disposal and how do they exploit their truncated multilingual repertoire within different social settings? The sociolinguistic and ethnographic empirical observations have yielded useful information on the multiple usages of languages by our participants. This paper reveals how several languages are handled in the daily life with limited or high competence in each of them displaying the intricacies of truncated multilingual repertoire. The latter has been found playing a pivotal role in situating language practices with different segments of the society.
\end{abstract}

Keywords: truncated multilingual repertoire, truncated competencies, language practices, language inequality, religious languages, Indian immigrants in France, Norway and Finland

\section{Introduction}

A considerable amount of research can be found on language practices of migrant communities, but it has been noticed that less attention has been paid to their language competency. The sociolinguistic practitioners have accorded less importance to the competencies in the spoken or written language of an individual, rather focusing on the variational dynamism of the language combining with its specific social factors. Language tests have been introduced in Europe aiming the immigrant groups (Extra et al. 2009, Shohamy 2006: 36) by the policy-makers in the name of sociolinguistics assimilation toward the host 
country. Such policies which undermine the essential attributes of human rights and determine their existence on the parameters of language skills make an important criterion for inclusion or exclusion of the concerned individual from a territory. Therefore, it implies a plea for more sociolinguistic expertise to constitute new ideas and theories to counteract such hegemonic beliefs and valorise multiple language practices irrespective of the competencies. This paper distances itself from language test topics as it is not the main objective, but it will attempt to highlight the practices and competencies of all the languages (not in the construal tradition) reported by three Indian immigrant family members in three European countries - France, Norway and Finland.

A two-dimensional approach will be raised to address language competency issues from sociolinguistics and ethnographic perspectives; the first approach focuses on "language inequality" in order to comprehend the unequal distribution of languages in the verbal repertoire of Indian family members, and the second focuses on "language resources" available to these participants to understand the mechanism behind the varied language competencies. In this manner, a collective process of language trajectory can be captured which is vital to elucidate different facets of language skills.

Blommaert et al. (2005: 197) argue that the term multilingualism does not necessarily mean full competence in a given language, but rather it is the environment which enables and disables such competencies in a given time situation. The same authors refer to the works of Haviland (2003) and Urciuoli (1996) to further state, "the phenomenon of "truncated multilingualism" is linguistic competencies which are organized topically, on the basis of domains or specific activities [---]". They recognize that "truncated competency depending on scalar judgment might be "valued assets" or dismissed as having no language". In this study, we argue a similar position suggesting that multiple language practices, particularly in diasporal scenarios, entail varied language skills in one's verbal repertoire.

\section{Methodology and hypotheses}

This paper is based on an empirical study of Indian families in which the first generation of a family represents a unit of 
study and shares homogeneous linguistic and cultural practices. The fieldwork study was made prominent and more emphasis was put on empirical data to capture the real linguistic practices of family members. Ethnographic methods were employed to yield insightful events to comprehend the political and ideological aspect of the participants' attitudes toward language. The qualitative method is the main approach which served as the guideline in the data collection and the analysis procedures. The tools and methods employed for the data collection were: (i) questionnaire (open-ended), (ii) interviews (recorded), (iii) conversation recording of family members, (iv) participant observation, (v) triangulation, and (vi) member-checking. A large range of tools and methods were conducted to cross-check and verify the information given by participants. Data was gathered at various times for each family: from 2003-2008 (family in France) and from 2007-2010 (families in Norway and Finland). The transcription of data collected was carried out on the pattern from LIDES coding manual (Barnett et al. 2000). It seems appropriate to follow this transcription guideline for the members of Indian communities who have three to four languages in their verbal repertoire. The software tool, Transana ${ }^{1}$, was used to transcribe, analyze, and organize the data.

Some hypotheses which can be tested regarding the language skills and verbal repertoire are as follows:

I) The number of languages spoken by our participants in a monolingual or bilingual setting(s) is reduced as some languages might no longer be used at all;

II) The more languages present in the verbal repertoire, the more chances that the language skills of the individual is truncated;

III) The language skills of the first generation in the host language(s) is truncated;

IV) The language skills of the second generation in their parent's first language are highly truncated owing to less exposure and lack of formal instruction in these languages;

V) The language attitude of the speaker determines the degree of language competency in a particular language.

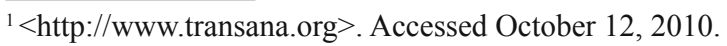


These assumptions, which I have taken as my starting point, will be discussed and verified throughout the paper. For this purpose, the roman numerals will be utilized to refer to the hypotheses, if needed.

\section{Sociolinguistic historical background of the families}

The first generation of all the families were brought up and educated in a multilingual environment before migrating to Europe. The parents are therefore, adept in exploiting and maintaining all the languages in their verbal repertoire, and they have tried to transmit the same practices to their children.

The focus of the research in my doctoral dissertation ${ }^{2}$ is to determine the language practices based on the homogeneous linguistics and culture backgrounds of a migrant community, by focusing on the transmission, political linguistics, and language practices of the second generation and its various ramifications on their identities. The main characteristics of the family profile which I sought to study are hereafter:

- the family must be an Indian migrant couple with both parents sharing the same first language(s) and preferably from similar geographical background;

- the family is migrated in the sense that one of the family members should have a long-stay work permit so that s/he can settle with no difficulty in the resident country.

In the sequential order to which I came to know the families, I codified these families for the purpose of easy reference: FAM A for the family in Grenoble, FAM B for the Trondheim family, and FAM C for the Helsinki family. All these families have some features in common: (i) they all come from North India; (ii) one of the official languages of all the States from where they originate from is Hindi; (iii) the father provided most of the family's income, and they are all well-educated; (iv) the first generation studied Hindi and English during their studies and can speak both languages; (v) the first generation speaks or has spo-

${ }^{2}$ Dissertation topic "A sociolinguistic and ethnographic case study on Indian migrant families across Europe: Language practices and political linguistics of the nations \& families". 
ken in their first language with their parents; (vi) all the families have maintained strong connections with their home country and they visit their hometown at least once in a year.

\subsection{Linguistic profile and language practices of the first generation}

FAM A (Grenoble) comes from Haryana, a state in Northern India where Hindi is the official language ${ }^{3}$, and Haryanvi ${ }^{4}$ is widely spoken by its inhabitants. Since this state was carved out of Punjab, the Punjabi language and culture is spread into Haryana.

The parents have the same first language (i.e. Haryanvi) and the father commands other languages such as Nepali, Punjabi, Hindi, English, and French. The mother reports her competency in Hindi, English, and French in addition to her first language (Haryanvi).

The monolingual setting of France made learning French a compulsory step as part of sociolinguistic assimilation. The father (52 years) $)^{5}$ migrated in 1980 and learned French in an informal way; interaction with locals, watching television, hearing radio programs, and making friends. He worked as a businessman before he died of a heart attack near Grenoble (April 2008). The mother (39 years) learned French formally in private institutions and continued her undergraduate English program in a French University with French students. She worked as an assistant English teacher in a local lycée in Grenoble for over two years. Later, she opened a French institution to teach French language in Gurgaon (India). After the death of her husband, she took the responsibility of the business in Grenoble, and at the same time she was managing her institution in India.

FAM B (in Trondheim) hails from Bihar, a state in the eastern part of India, where Hindi is the official language, and Urdu occupies the state's second official language which is also the first language of both parents.

\footnotetext{
${ }^{3}<\mathrm{http}$ //www.tlfq.ulaval.ca/axl/asie/inde-3pol-etats.htm $>$, primary source of official languages and States of India. Accessed September 08, 2008.

$4<$ http://www.ethnologue.com/show_country.asp?name=IN $>$, primary source of all Indian languages cited here. Accessed September 08, 2008.

${ }^{5}$ The age of all the participants corresponds to their age in the year 2008.
} 
The father (46 years) speaks Hindi, Urdu, English, and Norwegian while the mother (36 years) has reported similar language competencies, but remains highly truncated in English and Norwegian. The practice of Norwegian language is, however, restricted to special occasions.

The provider for the family is the father who came to Trondheim as a PhD candidate, and upon completion of his thesis, he joined the company administered by his advisor (an American). The company's language is English, and most of their clients (worldwide) speak English. He learned Norwegian during his $\mathrm{PhD}$ studies as an optional subject and never felt the necessity to continue learning the host language. The mother is a housewife who has learned Norwegian for eleven years as a hobby.

The members of FAM C (in Helsinki) originate from the same state as FAM B, Bihar. The parents share the same first language (Urdu), and learned Hindi and English during their school and university studies. The father (35 years) knows Malay as he studied it as an optional subject during his PhD Studies in Malaysia for two years. The mother (30 years) has been learning Finnish for one year.

The father worked as an engineer in a cellular telephone company whose official language is English. He didn't learn the Finnish language, and he does not feel the need to learn it. The mother is primarily a housewife, but she worked in a local English daycare centre for one month in 2007. Since April 2009 she has been working as an assistant school teacher in a Finnishmedium school.

\subsection{Linguistic profile and language practices of the second generation}

FAM A has one 16 year-old girl and one 14 year-old boy who were both born in France. In the questionnaire, the girl reported Haryanvi as her first language (though she never spoke it) while the boy reported French as his first language. The data collected during the fieldwork between September 2004 and June 2005 indicate strong presence of French language inside the home where children forced their parents to converge in their favourite language (French) whenever the parents switched to other Indian languages (Haque 2010a: 166-167). The parents decided to send 
the children to India for their further schooling in July 2005. According to the parents, learning Indian languages such as Hindi and having more exposure to English and Haryanvi will create more linguistic and social opportunities for their children in India and they can build up their own social network. There was a remarkable change in the verbal repertoire of the children during their first six months of stay in India: the conversation among the family members recorded in December 2005 was dominant in the Hindi language. Both children are still continuing their studies in India whereas the mother works between France and India.

FAM B is composed of four children besides parents. There are two boys who are 17 years and 14 years-old followed by two girls of 8 and 5 years-old. The boys were born in India, and their sisters were born in Norway. They all reported Urdu as their first language. Due to the differences of age and schooling, they have different linguistic repertoire. The youngest child reports her competencies in Urdu and Norwegian languages. Her elder sister can speak Urdu and Norwegian, and she is learning English at school. The boys report themselves fluent in spoken Urdu and Hindi although their schooling is in Norwegian. All the children except the eldest son have been sent to English daycare before going to Norwegian-medium schools. The eldest son arrived in Norway at the age of 5 years-old. He did one and a half years of schooling in India, and therefore, he seems more proficient in spoken Urdu/Hindi than his siblings.

FAM C has two boys around 10 years and 4 years-old. The eldest son went to an English daycare school before going to an English-medium school in Helsinki. He speaks Urdu as his first language and is learning written Urdu and Hindi (alphabets, grammar exercises) at home. He is having three FSL classes (Finnish as a second language) for two hours each week. The younger child is going to a Finnish daycare, and he understands spoken Urdu.

The linguistic and biographic trajectories of both generations reflect an understanding between the differences in language practices and language attitudes. The parents not only have undergone a multilingual setting in the formal manner (institutions, government authorities, schools, hobbies, etc.) but also in an informal manner (exposure to multiple language practices in their day to day life) in their country of origin, whereas the children were raised in monolingual (France) or bilingual (Norway and 
Finland) settings. The children do not speak or do not have the knowledge of as many languages as the parents have reported for themselves.

\section{Multilingual repertoire and truncated competencies}

Multilingual repertoire can be regarded as an important phenomenon in this globalized world. The term repertoire has been defined by Hymes (1996) as "a set of ways of speaking" which comprise of "speech styles" and "contexts". We can infer that in a multilingual repertoire, an interlocutor has different sets of ways of speaking owing to the presence or/and usage of different languages according to the needs and representations of the society in a given space. The particularity of truncated multilingual repertoire is illustrated by Pillai (2002) when he evokes the importance of communicative competencies (which may be also referred as truncated) in an individual in India as "he may speak a regional dialect with a person belonging to the same region; he may speak a caste dialect with a person belonging to the same caste, and a standard or some other dialect with the speakers of other regions and castes". In such instances, an individual will manifest a different repertoire of different languages resulting in various types of competencies in several languages which can be considered as truncated competencies. Thus, the truncated multilingual repertoire comprises different linguistic competencies in one or several languages including its variants, in any of its forms, either fluent, limited, or restricted in communication or an abstract knowledge of an unpracticed language besides skills in shifting accent, register and styles of a given language in different domains and different spaces.

The preliminary findings revealed the presence and practices of all the languages reported by our respondents. Therefore, it does not hold the first hypothesis that there will be language attrition in a monolingual or bilingual location such as France, Norway, and Finland. Further investigation during the fieldwork provided ample evidence of multiple language usage by the family members. Moreover, religious languages, which were not reported by any of the participants, were found to be employed during ritual ceremonies or to perform religious duties. Further 
details regarding the religious languages will be discussed later in this section.

The use of native and host languages in the daily life of family members does not rely upon the competency in each language, but it has to do with language policies and attitudes that the parents want to implement in the household. French was the sole dominant language for FAM A in all the activities for family members whereas usage of Haryanvi or Hindi was restricted between parents. The latter demonstrated a good command in spoken French during one of the conversations recorded between them and their children. In 2005, the mother took both children to her country of origin in order to transmit the cultural and linguistic heritage, while the father looked after his business in France. The children were not admitted into a Hindi-medium school, but into an English-medium in order to learn English which the parents preferred. Hindi was learned through daily interaction with peer groups and family members as well as in school as a subject. After six months of their stay in India, the children acquired enough skills in Hindi to carry out conversations with their parents, and they gave their interview in 2007 in the Hindi language.

In FAM B, the father reported his Norwegian to be a 3 on a 5-point scale. Among his activities, he listens to radio and reads the newspaper in Norwegian during breakfast. Also, he watches the cartoon channel in Norwegian with his youngest child. The children were prohibited to speak in Norwegian inside the home, and they were able to talk easily in Urdu despite receiving no formal instruction in the language in school or at home. The mother attends Norwegian classes two hours a week, and complains that no one among the family member is willing to talk to her in Norwegian. The reason she cites, is her status in the home as a debutant in Norwegian, but paradoxically, she is the victim of her own policy that no one should speak Norwegian at home.

In the case of FAM C in Finland, the father expressed his opinion that the Finnish language has no utility in his professional life as he can perform his job in English. Furthermore, according to him, "Finnish is not needed to lead a normal life in Finland as English can be used in almost all activities" (translated from Urdu). Similarly, he found no use of transmitting his native languages to his children. For him, it will only be English that can play a vital role in the career enhancement of his infants, although he was found to speak primarily in Urdu language 
with both of his sons. The father reports no knowledge of the Finnish language, although he can converse with his youngest child in the Finnish language. The conversations are rather ludic in nature, and their usage is limited to small phrases and words such as, mitä se on (what is it), mitä (what), hyvä (good), and so forth. In one instance, he uttered some Finnish words which I was surprised to hear, and his wife explained, "oh he is living here since very long time, it is natural that he will know some words"(translated from Urdu). The mother, on the other hand, was found passionate about learning the Finnish language. The usage of the host language in her case is limited to outside of the home either on the school premises or with her new network of Finnish speaking friends. Because the youngest son is enrolled in Finnish daycare, the mother tries to carry out conversations with him in Finnish inside the home.

Languages are employed by family members in an unequal manner relying not only the resources which they have in that language, but also by shifting from one language to another according to the specific domain. The attribution of languages to different domains highlights its functional features, which is one of the focal points of interest and research in sociolinguistics. According to Annamalai (2001: 36):

[f] unctional distribution of languages helps the languages not to be in conflict with an individual. One language is for ethnic identity, another for business transactions, another for official dealings, another for entertainment, another for rituals and so on.

The parents have been found to employ or use another language at their workspace. In the case of FAM A, the father had only elementary knowledge of standard French, but he carried out his handicraft business with his French clients for more than twenty years. Not having adequate skills in the host languages of Norway and Finland, the fathers in FAM B and FAM C use the English language during their office time. The professional skills of the fathers in the cases of these families predominate over their language skills to perform their job in English (for FAM B and FAM C) or in French (FAM A). With a very limited knowledge of the Finnish language, the mother in FAM C worked as an assistant teacher in Finnish school. 
Verifying the third hypothesis that the language skills of the first generation in the host language is truncated is confirmed for the fathers of FAM A, B and C and the mother of FAM B, whereas the improved language skills in the host languages of the mothers in FAM A and FAM C can be attributed to hypothesis $(\mathrm{V})$. As pointed out in $(\mathrm{V})$, the importance of language attitude determines the degree of language competency, it holds true for these mothers in the sense that they are highly motivated to learn and have jobs related to the host languages. It also holds true in the case of the fathers whose language skills reflect their language attitudes which vary from high for FAM A, middle for FAM B, and low for FAM C.

The language skills of the second generation are found equally messy and truncated in each family. In the family of FAM $\mathrm{C}$, the home language instruction by the mother was successfully implemented, and yielded satisfactory results as both children of this family speak Urdu at home. For FAM B, though no home language instruction is reported, the family variegates by travelling to the country of origin, inviting Urdu-speaking relatives to Norway, and has a strict code of speaking Urdu inside the household in order to orient their children toward the Urdu language. In the case of FAM A, the recourse to remigration to India was an exceptional step taken by the immigrant family to rekindle the cultural and linguistic practices of the parents. The delayed learning of Hindi for the children in FAM A and limited exposure to Urdu in FAM B and FAM C result in a highly truncated competency which confirms the hypothesis (IV). In an interview, both parents of FAM A narrate the difficulty of written Hindi for their children in Indian school, although their oral conversation uniquely dominates in this language. The children of FAM B and FAM $\mathrm{C}$ seldom have occasion to write Urdu, and their spoken skills rotate around few verbs and limited lexical chunks. Here is an extract of a conversation in the house of FAM B in which one can notice the lack of skills in the Urdu language:

SZN - myself, MUS - male child, 14 years, FAZ - father, 46 years

SZN (to MUS): (pointing fingers toward smashed potatoes) what do we call this?

MUS: this one, ah ah, what do we call it? 
SZN: bharta (a colloquial term used for smashed potatoes in Urdu in Bihar)

FAZ (to MUS): haven't you eaten it in India?

MUS: yes, I have eaten but I didn't know...

This is an extract of conversation from the dining table where I was invited to eat with the family members. RAF (17 years), the elder brother of MUS (14 years) was also present, and he kept silent. We were eating one of the regional specialties, and the children who were brought up in Trondheim were not able to express the term for smashed potatoes in Urdu. Similar trends have been observed in the case of second generation from FAM C in Helsinki. As far as the children of FAM $\mathrm{A}$ in France are concerned, they are found to have an adequate knowledge of the Indian culinary terms. One might then question the discrepancies in language competency of these children particularly in the specific domain related to cuisine. During the fieldwork conducted on FAM A, it was found that the father used to specify the name of each item in Haryanvi during the meal with the children; whereas the parents in FAM B and FAM C ignored to employ the specific term in their first language. The demonstrative pronouns this and that were utilized if a particular item was referred. The parents would say to their children would you like to eat this? And the children were found to use the phrase give me that please.

For religious and ritual purposes, the children of FAM B and FAM $\mathrm{C}$ from the Islamic background have learned Koranic Arabic to read the holy book and offer prayers. Competence is restricted to read Arabic in such a manner that they cannot read Arabic journals, but they can read the Koran and learn the verses to recite during the prayers. The parents have been found to have similar competency in both families. They do not understand the meaning of Koranic verses, although they learned some of them to perform the religious duties as prescribed in the religion; the translations are, however, always available in the holy book with one page in Arabic and the other in languages preferred. FAM A, whose members are Hindu, did not have any religious language training as they rely more upon the priest to perform religious ceremonies. In the temples, the rites and rituals are performed in the Sanskrit language that the family members do not understand. Language competencies in classical Arabic or Sanskrit for these 
members might develop in a truncated manner with passage of time. Such truncated competencies emanating from theistic literatures are more lexical in nature than syntactical, as the lexeme can be understood in a parabolic text or sermon with frequent or repeated exposure.

Each family member has three to five languages in his/her verbal repertoire. Lakha and Stevenson account (2001) several instances of diverse linguistic codes among Indian immigrants in Melbourne which they argue originate from the "heterogeneous cultural practices" and which according to the authors "help maintain the link with the homeland". The presence of several languages does not preclude high-level skill in each of them, but on the contrary, it has been noticed that the language skill is truncated, validating the hypothesis number (II). All the instances which have been accounted here are either for host languages, native languages, or religious languages. The language diversity and choices for our respondents are large but tailored for specific activities. It has been further discovered that the participants cannot satisfy some of their needs in their own native languages. For instance, jobs cannot be executed in Urdu, Hindi, or Haryanvi from the fathers as their linguistic competencies in these languages were not sufficient to perform the task. However, this issue is not confined to space-related frame. Even if our respondents were working in India, they would need or resort to English to perform similar jobs. This is for the primary reason that these tasks or jobs, either in advance software programming or conducting engineering operations, do not have adequate infrastructure in other Indian languages. Mir et al. (2000) identify the importance of English in the software industry either in India or in the verbal repertoire of four Indian immigrants to United States on whom the case study was conducted. One cannot imagine the practice of Urdu and Hindi languages in advance scientific studies as the developments and publications of major findings in this field is dominantly done in English. The viewpoint of McClure (1979: 40) related to the Scots language can very well illustrate the continuous degenerating state of languages in India at the expense of English, "it has suffered a massive attrition of its active vocabulary and a progressive dilution of its distinctive grammatical and phonological features". The language inequality in this regard is not a space problem, but it is related to the power and prestige assigned to a particular 
language. We can also understand why the parents in all the cases emphasize that their children learn English in order to be successful in their host country or country of origin.

\section{Measurement and evaluation process of truncated competencies}

The truncated competence has no evaluative importance. Though one can evaluate with different remarks one's own skill as satisfactory, very satisfactory, and so forth, but one cannot measure its exactitude. The auto-evaluation of family members regarding their competency in the languages known to them were asked through questionnaires and further investigated during in-depth interviews and conversation recordings. Though the self-appraisal techniques by respondents have their own drawbacks, Boyd (1985: 141) argues "they can at best be taken as a rough guide to how much confidence the respondents have concerning their skill [...]". The father in FAM C did not evaluate his competency in the Finnish language in the questionnaire and left the space blank. When I reminded him by e-mail if he could auto-evaluate his Finnish language skill, he replied "you can put me zero everywhere" (in reading, writing, speaking and oral comprehension). For the English language, the father narrated an incident in which he had to pass an entrance test to pursue his $\mathrm{PhD}$ studies in Ireland, "I had an entrance exam (of English language) and there was a question asking about the female of the dog and I wrote doggy" (translated from Urdu). Prior to this test, he completed his university studies in English (Bachelor of Engineering, New Delhi and Masters in Engineering, Kuala Lumpur), but the local language practice for him was Hindi/Urdu in India and remained same in Malaysia with select Indian friends. Thus, his English language skills can be viewed as truncated and limited to the specific domain of scientific English. As Blommaert (2010: 104) points out his skills in English, "it entered my life as a professional tool, and this explains the absence of vernacular varieties", we may interpret the same reason for the father in FAM C.

Examining the trajectory of the immigrant family members, the practices of host languages, native languages, or English as recourse are deployed either in the host country or in the coun- 
try of origin. Blommaert (2003: 613) argues, "[w]hen people move across physical as well as social space, their language practices undergo re-evaluation at every step of the trajectory and the functions of their repertoire are redefined". Not one language can address all of the different functional needs of participants, which result in varying skills in the verbal repertoire. For the fathers in FAM B and FAM C English is third after Urdu and Hindi, but occupies a vital role in their jobs. The mother in FAM A teaches French in India as she acquired the skills in the language during her long stay in France instead of a university degree required to exercise such function.

The language skills of second generations in sociolinguistic studies do not often subscribe to the language evaluation test as prescribed by the educational bodies, but the motif is to extract the real language practices through questionnaires and in particular by recording of interviews and conversation. Another tool which has been particularly useful in this regard was following the language employment of the second generation on Facebook. This web-site of social network where I asked the children to add me as a friend provided a platform to analyze the usage of all or some of the languages in their verbal repertoire with their peer groups, friends, and family members. Later, I added some of the parents (father in FAM B and both parents in FAM C) who were also on Facebook. It shows the real linguistic attitudes of the participants, and their usage of language(s) can be observed as why and how they employ a particular linguistic code.

\section{Conclusions}

The purpose of this paper was to draw some attention toward the notion of language competency which poses a new challenge to theorize the multiple layers of skills in a person's repertoire within an immigration context. The major compelling issues such as language and educational policies and the attitude of immigrant languages by the host societies are skipped in this paper though they largely relate in the construction and shaping of verbal repertoire. This was not raised as it was beyond the scope of this paper.

The postulates related to the language practices and truncated language skills converge with the findings except (I) in 
which I assumed that the number of languages spoken by immigrant family members would diminish. The findings of the current study do not support the previous research which have indicated a sharp decline in the first or native language(s) in an immigrant household (Rezzoug et al. 2007, Deprez 2000, Rumbaut et al. 2006, Moore 2007, Matthey 2010). These families have made an exceptional effort to maintain all the native languages despite employing the host languages in the case of some members. Based on my experience, I have myself acquired and observed the immense diverse truncated linguistic codes during my residence in India. The truncated multilingual repertoire is a common phenomenon in India where people from all socialeconomic backgrounds might learn few lexical words of the languages spoken around them to widen the communication network. English is the language of predilection in the three cases of families studied where its employment and importance have been noticed. The use of host languages between parent-child has not been found. The parents of FAM B and FAM C speak in the first language with their children whereas the parents of FAM A speak in their second language (Hindi) with them. All the members employ the host language(s) in their daily life according to the function allotted by them. In the matter of religious beliefs, knowledge of limited, but essential parts of Arabic helps all the family members in $\mathrm{B}$ and $\mathrm{C}$ to perform the religious duties, whereas the children of FAM A have reported no knowledge of Sanskrit compared to their parents as they rely more on the priests to perform the rituals.

The second generation who can speak the first language of their parents even if they are not able to write (in case of FAM B for Urdu and Hindi and FAM C for Hindi), can not only communicate in these languages with their parents, but also with other fellow Indians in India or abroad creating their own network independent of their parents. In one such instance, RAF (eldest son of FAM B) interviewed manual labourers in Hindi outside a railway station in India to present his work in his school in Trondheim. By not speaking the parental language(s) at all might have cut all their relations and links with their country of origin, and later it would have been difficult to associate even to their parents who speak different languages and have different cultural norms.

Responding to our earlier observations, "is truncated competency decisive for the maintenance of native languages and the 
perseverance of affective links with one's culture" (Haque 2010b: 234), we demonstrated in this study that the migrant subject's truncated multilingual repertoire serves highly conjunctive with the social needs and tasks. The language deficiency or lack of required skill in a given language is not viewed as a hindrance to perform most of the daily functions, but the problem though remains that the truncated competencies stay static in nature. To overcome, it is the person who is the most apt to review, monitor, forego, or develop the language skills in his or her verbal repertoire.

\section{Acknowledgement}

I would like to express my thanks to Prof. Anju Saxena who asked me to write a paper on truncated competency, and her suggestions enhanced the quality of work. My thanks go to Senior Lecturer, Sirkku Latomaa who gave me valuable comments on the first draft of this paper. I am very grateful to Prof. Jan Blommaert for his series of lectures and discussions related to this topic which I attended at University of Jyväskylä. I am most indebted to Prof. Jukka Havu for his cooperation and interest in my research. This paper would not have been possible without the support of Swedish Institute Scholarship and CIMO Fellowship, Finland.

\section{Address:}

Shahzaman Haque

LIDILEM

Université Stendhal Grenoble III

BP 25 - 38040 Grenoble

France

E-mail: shahzaman.haque@gawab.com

\section{References}

Annamalai, E. (2001) Managing multilingualism in India: political and linguistic manifestations. New Delhi: Sage.

Barnett, Ruthanna, Eva Codó, Eva Eppler, et al. (2000) “The LIDES coding manual". International Journal of Bilingualism 4, 2, 131-270. 
Blommaert, Jan (2003) "Commentary: a sociolinguistics of globalization". Journal of Sociolinguistics 7, 4, 607-623.

Blommaert, Jan (2010) The sociolinguistics of globalization. Cambridge: Cambridge University Press.

Blommaert, Jan, James Collins, and Stef Slembrouck (2005) "Spaces of multilingualism". Language and Communication 25, 3, 197-216.

Boyd, Sally (1985) Language survival: a study of language contact, language shift and language choice in Sweden. (Gothenburg Monographs in Linguistics, 6.) Göteborg: University of Göteborg.

Deprez, Christine (2000) "Le jeu des langues dans les familles bilingues d'origine étrangère”. Estudios de Sociolingüistica 1, 1, 59-74.

Extra, Guus, Massimiliano Spotti, and Piet Van Avermaet (2009), eds. Language testing, migration and citizenship: cross-national perspectives on integration regimes. London: Continuum.

Haque, Shahzaman (2010a) "Enjeux des politiques linguistiques: pratiques et comportements langagiers multilingues dans un pays monolingue". In Maria Iliescu, Heidi M. Siller-Runggaldier, and Paul Danler, eds. Actes du XXVe congrès international de linguistique et de philologie romanes. Tome I, 163-172. Berlin: Walter de Gruyter.

Haque, Shahzaman (2010b) "Place des langues natives et d'accueil chez trois familles migrantes indiennes en Europe”. In Andrea Rocci, Alexandre Duchêne, Aleksandra Gnach, and Daniel Stotz, eds. Bulletin Suisse de Linguistique Appliquée 1, 225-236.

Haviland, John B. (2003) "Ideologies of language: reflections on language and US law". American Anthropologist 105, 764-774.

Hymes, Dell (1996) Ethnography, linguistics, narrative inequality: toward an understanding of voice. London: Taylor and Francis.

Lakha, Salim and Michael Stevenson (2001) "Indian identity in multicultural Melbourne. some preliminary observations". Journal of Intercultural Studies 22, 3, 245-262.

Matthey, Marinette (2010) "Transmission d'une langue minoritaire en situation de migration: aspects linguistiques et sociolinguistiques". In Andrea Rocci, Alexandre Duchêne, Aleksandra Gnach, and Daniel Stotz, eds. Bulletin Suisse de Linguistique Appliquée 2010/1, 237-252.

McClure, Derrick J. (1979) "Scots: its range of uses". In Adam J. Aitken and Tom McArthur, eds. Languages of Scotland. Edinburgh: Chambers.

Mir, Ali, Biju Mathew, and Raza Mir (2000) "The codes of migration: contours of the global software labour market". Cultural dynamics 12, 5, 5-33.

Moore, Robert E. (2007) "From endangered to dangerous: two types of sociolinguistic inequality (with examples from Ireland \& the US)". (Working Papers in Urban Language and Literacies, 45.) London: King's College. 
Pillai, N. Nadaraja (2002) "Teaching communicative competence in diglossic Indian languages". Language in India 2, 2. Internet journal <http:// www.languageinindia.com/april2002/nadarajapillaidiglossia.html>. Accessed March 20, 2009.

Rezzoug, Dalila, Sylvaine De Plaën, Malika Bensekhar-Bennabi, and Marie Rose Moro (2007) "Bilinguisme chez les enfants de migrants, mythes et réalités". Le français aujourd'hui 158, 3, 61-68.

Rumbaut, Rubén G., Douglas S. Massey and Frank D. Bean (2006) "Linguistic life expectancies: immigrant language retention in southern California". Population and Development Review 32, 3, 447-460.

Shohamy, Elana (2006) Language policy: hidden agendas and new approaches. Oxon: Routledge.

Urciuoli, Bonnie (1996) Exposing prejudice: Puerto Rican experiences of language, race, and class. Boulder, CO: Westview Press.

Kokkuvõte. Shahzaman Haque: Erinevates Euroopa linnades elava kolme India sisserännanute perekonna piiratud mitmekeelne keelekasutus. Artiklis kirjeldatakse juhtumiuuringut kolme India päritolu sisserännanute perekonna keelevalikutest. Keelejuhid elavad kolmes Euroopa riigis: Prantsusmaal, Norras ja Soomes. Artikli fookuses on sisserännanute keelekasutus olukorras, kus kõnelejate verbaalne repertuaar koosneb piiratud keeleoskuse tõttu mitmest keelest. Milliseid keeli nad räägivad ning kuidas nad piiratud mitmekeelset repertuaari erinevas sotsiaalses ümbruses kasutavad? Sotsiolingvistilised ja etnograafilised empiirilised tähelepanekud annavad vajalikku teavet keelte erinevate kasutusviiside kohta nende keelejuhtide näitel. Artiklis kirjeldatakse, kuidas kasutatakse mitut keelt igapäevaelus piiratud või hea keeleoskuse korral; samuti nähtub, kuivõrd keerukas on piiratud mitmekeelne repertuaar. On väidetud, et viimane mängib otsustavat rolli selles, millist keelt ühiskonna eri segmentides kasutatakse.

Märksõnad: piiratud mitmekeelne repertuaar, piiratud oskused, keelekasutus, keeleline ebavõrdsus, religioossed keeled, India päritolu sisserändajad Prantsusmaal, Norras ja Soomes 